Marquette University

e-Publications@Marquette

College of Education Faculty Research and

Publications

Education, College of

$2-1-2013$

Students' Peer Interactions Within a Cohort and in Host Countries During a Short-Term Study Abroad

Jody Jessup-Anger

Marquette University, jody.jessup-anger@marquette.edu

Aileen Aragones

Admission Possible

Published version. Journal of Student Affairs Research and Practice, Vol. 50, No. 1 (February 2013):

21-36. DOI. (C) 2013 Walter de Gruyter. Used with permission. 
Jessup-Anger, J. E., \& Aragones, A. (20|3).

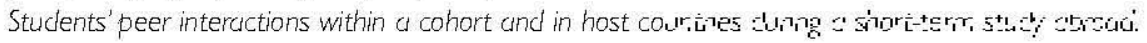

Journat of Student Affars Research and Practice, 50(1), 21-36.

doi: 10.1515/jsarp-2013-0002

Available at http://dx.doi.org/10.15/5/jsarp-2013-0002

Innovations in Research and Scholarship Feature

\title{
Students' Peer Interactions Within a Cohort and in Host Countries During a Short-Term Study Abroad
}

Jody E. Jessup-Anger, Morụtetete Unnersit'

Aileen Aragones, Adrmission? Possible

\begin{abstract}
零
In this qualitative case study, we explored sudents peer interotors

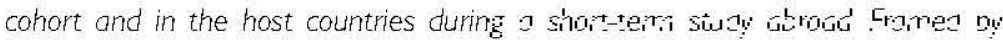

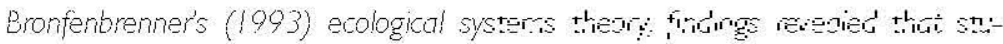
dents spent considerable energy refecting on wioctons with pers. The students considered themselves loners. mediotors. messengers ara lowr ers. Findings ithustrate the need to ater: to students afferirg personi attributes and relationships with peers, os these offect trour oricil cxomiences.
\end{abstract}

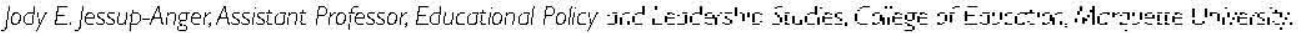
Aileen Arogones, High School Progrom Coordinator, Admission Pass'ble

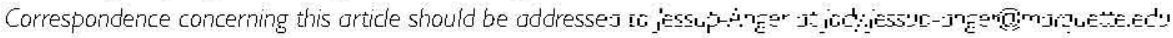


Concurrent with the increase in the number of strdents studying a inmad ner the past thirty five years (Institute of International Education: 20ll) is a change in the way they do so that has repercussions for students' experiences while a omad. Hiscorically; students sper.t a semester or more abroad and lived with a family or stayed in a dormitory isolated from ot her Ámeriauns (Institute of International Education, 2011); today many studentschoose to attend faculty-led programs during which they travel with a cohort of peers (Ergle \& Engle; -999). This change in the structure of study abroad potentially limits students' integration ir-w the kost cc.lcure and heightens their interactions with other domestic students.

In addition to raising questions about the effectiveness of the short-term format in zromoting cross-cultural learning (Dwyer, 2004; Engle \& Engle, 1909; Irgrah:am \& Fetersor, 2004; Paige, Fry, Stallman, Josic, \& Jon, 2009), cohort-based programs raise c cestions a onot the role of peers ir students' experience. A cohort is a small group of learners who somple te a pmgram of strdy tongether (Lawrence, 2002). The cohort based, short-term study a omad experience creates a tricue cortext for fostering relationships and learning amorg peers. Unlike ir traditinnal classronms where learners spend several hours together and then part ways, ir cohorc-bassd study abroad programs students are forced to interact continuously with the same peers. These interactiors increalse the importance of understanding the cohort as a learnirg envimrment, rscogrieirg its potertial to enrich peer learning or increase conflict and feelings of marginalization (Ranstury \& Harris, 1994). In a reflective essay, Lenz and Wister (2008), two faculty memiers who spent ten years leading short-term trips to Central America, credited the preserce of a cohnre with providing "a comfortable set of personal and group relationships [and] ar ideal space ir which wo express [their] deep" est thoughts safely...." (p. 86), but little research exists to susstantiate their claim.

Although several researchers explored the experiences of students in cohort-based pmgrams, their studies focused on outcomes, investigating glotal awareness (Chieffo \& Griffiths, $20 \mathrm{c} 4$ ), culture learning (Brubaker, 2007), long-term impact (Rowar-Kenyor \& Nichar.5, 201$]$ ), and gerder identity (Jessup-Anger, 2008; Twombly, 1995) ard not or students' irteractions with their peers. Only Ransbury and Harris (1994) explicitly investigated the mle of the colort ir the experienses of students engaged in a short-term program. Using partisipart nbservatior methods, the authors found that the presence of the group influenced jetavior, as stucents were simultaneously engaging in a group process and adjusting to a new cclttre (Rar-sury \& Harris: 994 ). The rescanchers determined that group formation played a key mle ir. the scudents' behavinr ard not enotgh attention had been given to the group's interpersoral ir teractions. Althorgh their research pmoides evidence that cohort based peer interactions influence students: experiences, it stopsed short of examining students' perceptions of their roles anc. how these roles affected stucents' experiences with the host country, relying solely on observation notes (which would not have reflected tow students made sense of their interactions unless it was explicitj.

In the current study, we explored students per ir teractions withir their colort and in the host countries to understand the role of the cohort in students' experiences. Our specific reseanck 
questions were: (a) How do students describe their roles as group mem iers? and (o) How do they interact in the host countries (e.g., interactions with poople; fond, experiences)?

\section{Theoretical Framework}

Using Bronfenbrenner's (1993) ecological systems theory to uncerstand theinteractiveeffect of peers and developmental processes enables researahers to gair a more holistis r.rderstanding of the complexity of students' experiences (see Renr. \& Amold, 2003). The thenry ler ds itself to understanding students' interactions in a cohort of peers in study a onad becar se it provides ma.ltiple units of analysis; the student, the cohort, and the sor text of the host cour.tries Bronfer oremner (1993) envisioned development as a function of persm and envimor ment, with the interaction talsing place in the immediate setting in which the yerson exists. His mocel illustrates how zersonal attributes, called dovelopmentally instigative charactenstis, set ir motior "recipmal pmoesses of interpersonal interaction" (p. 12) that affect learning. He outlined four cyses of these characteristiss

Perhaps most relevant to exploring students' peer irteractinns ir study a amad is Timrfenbrenner's (1993) first type, personalstimulus characturistics, which details how ponples actiors irwiteor inhibit particular responses from the environment that car disrupt or foster psychologizal gmowth (eg, how peers might respond differently to a shy versus outgoing member of the cohord. Bronfenbrenner's second type, selective responsivity, describes kow penple ir teract with their strmotrdirgs (e.g., some students may immerse themselves fully ir the host cotntry yy chonsirg authentia fond and experiences, while others seek out comforts of home, chonsirg to dire at American fast-fond chains and mimicking activities they are used toj. The third type strictiring ing lnitics, details kow people seek out increasingly complex activities le.g., after some time, some students may elect to integrate more fully by separating from other Americars: Bscasse of the duratior of a skort-term study abroad, students' structuring proclivities my rot ie apparert. The fourth type, dructive bliefs, refers to how people view their agency in relation to their erwirmmene leg., studer.ts who believe they are cross-culturally competent may appmach interactiors with the host country with confidence, whereas students without such agency may be more passivej.

In a cohort situation, students possessing warying develnpmentally instigative characteristics interact with one another in addition to interactirg with members of the host wotr.ry. These interactions shape students' social integration, host conthery contast, ard their learring.

Another important aspect of Bronfenbrenners (1903) model is the cortext, descriod as the environmental characteristics that interact with the person anc affect cevelonmental processes Bronfenbrenner envisioned these characteristics as nested systems that strrourd an irdividual, from proximal to distal. He labeled these the micro, meso, coo, and macros tem.

Most relevant to understanding students' experier.es non a short-term stc dy a amad are sttdents' microsystems because they include the stucent anc study ajoac setting. The microsystem is defined by Bronfenbrenner (1993) as "a pattern of activities, roles, and intercersonal relations"

JSARP 2013, 50(1)

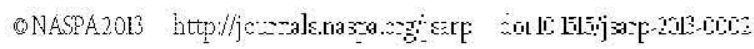

$$
\begin{aligned}
& \text { Brought to yo be | Uriters l: or hississ ppi }
\end{aligned}
$$

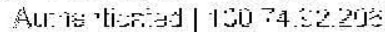

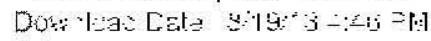


that are experienced in one's immediate environment that "irwite; permit, or inhibit ergagemerc" in that environment (p. 15). During a cohort-basod, skort-term stcdy a omad, many of stcderts" microsystems are identical, including their learnirg envimomert living arrangements, ard travel experiences. However, students bring their backgmands, expectations, and develnpmentally instigative characteristics (Bronfenbrenner, 1993) to the mismsystem.

The mesosystem, defined as "a system of two or more settings frec uentec. by the same person" (Bronfenbrenner, 1993, p. 20), details the linkages students may make to their shared mismsystems (the study abroad setting), which may include their home: family, or peer grous: while other elements of the context (exosystems and macrossstems) may affect stucents cevelonental processes and experiences, they are more distal and do rot wor tain the student. The surrert stt.dy focused on the interaction between the student, micrnsystem, and mesnsystem to tinderstard stzdents' peer interactions within their cohort and in the kost cotrerries during a short-term strdy abroad.

\section{Study Design}

We used a constructivist approach (Broido \& Marring: 2002) to explnes students" per irteractions within their cohort and in the host countries drring a short-term study abroad. The constructivist perspective (Piaget, 1972) aligned with our asst mptior. that sttdents ir teractions with peers and the host countries could not be urderstond as ar independent reality; rather, it would be rooted in context and include their previocs experiences ard perspectives as knowers. single qualitative case study design, framed by Timrfen iner rer's ( 993) scological systems theory, focused the analysis procedures. Because the unit of aralysis was the study abroad experiense, the ecological perspective enabled us to examine the studert, students' interactions with alch other, and the host countries simultaneously. Consistent with case strdy desigr (Yin, 1984), data were gathered at different points and through different meckanisms, including otservation, interviews and document review.

\section{Setting}

As detailed in Jessup-Anger (2008), the setting of the study was a three-wees, whort-osed study abroad program to New Zealand and Australia that tonk place in the summer of 2005 and focused on fond, environment, and social systems. It was sponsnred by Large Widwest Reseanch University, a public, research-extensive university located in the Widwest with more thar 20000 undergraduate students. A tenured faculty memier ard an administrator plar red ard led the trip. Twenty-eight students participated ( 19 womer ard 9 mer). The majority of studer ts were pursuing majors within the College of Agriculttre and Natural Resnuress, witk 15 stzdents ir agriculture-related areas and 5 in environmental studies or parks and recreation. The remaining 3 students had majors unrelated to the academic emphasis of the trip All of the str.derts knew one or more other students or faculty members through classes and friend hip prinr to the orier-catior.

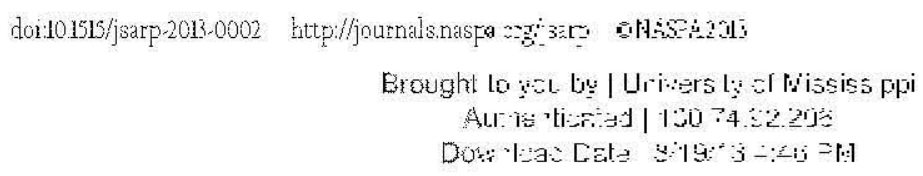

JSM̈RP 2013, 50!i! 
After flying together to the South Island of New Zealand, the entire grouz spent a week touring the island via bus. Tour guides, content experts (park rargers, farmersi and triversity administrators met the group and provided information. Ir. lieu of formal classes, the program facilitalors conducted two whole group reflection sessions while in New Zealand, asking students osen-ended questions about their observations of the host councry, reflecting on material provided $y$ y content experts, and encouraging them to relate their experieness to their existirg knowlodge. The group stayed together in hotels, where students shared rooms. Ore ererirg the grocp separated and stayed on several farms with families.

Thestudy tour continued to Australia, where the gmop spert two wedk torring the easterr coast. Instructional methods were similar to those ir New Zalland. While ir Ar.stralia, the program facilitators cond ucted two additional reflection sessions, asking stucents to relate their exeriences to existing knowledge. The group stayed in hostels or hotels, with students moming together.

\section{Method and Sample}

The first author was a participant observer in all formal anc most informal experiences [i.e., touring, residing, dining, and spending free days with stucients). The aurhor took felc notes of her observations 3 to 10 times each day, noting students' interactiors with alch nther ard the host countries (who they talked to, what they did). Notes were taker of all sttdents experiences, bt. the author made an effort to observe more closely the stucents who agreed to se zart of the interview portion. An outsider would have likely asscimed that the ar.thor was a parcicipant, jut stcdents were made aware through an announcement at nrier tacinr. that the at thor was cordtacting research about "the study abroad experience." At the erd of eack day, the author typed onsermatior notes and reflected on their meaning. In total, the author collectoc. 24 single syaced zages of osservation notes.

Second, the same author conducted two sets of irdividual, semistructtrad ir tervewes with 9 of the 28 students. Students were selected for interviews thmotgh pr.rposive sampling to arriveat maximum variation (Patton, 1990). Using autotiographies that were putlishec on a puslic wetsite set up for the trip and initial observation of the grouz: the author identifiec students who were diverse in terms of major, sex, social group, and ir terests and asked them to participate. Five female students and four male students completed both interviews. The participants were represer tative of the overall group in terms of sex, race/ethnicity; and major. Farticipants chnse or were assigred pseudonyms to protect their confidentiality (see Tasle l for demograzhics).

Each interview lasted between 45-75 minutes - the first took glace curing the seconc. half of the trip and the second about six weeks after the enc of the trip. In adcition to several c uestions about their observations of culture, the first set of interview questions solicitec students: feelings and reflections about their experiences, including "Have there been times on the trip where you have been uncomfortable, if so, when?;" "Have yor seer, felt, or experienced arything non the trip that has caused you to question any of your values?" ard "Are there aspects of the trip that yot:

JSARP 2013, 50(1)

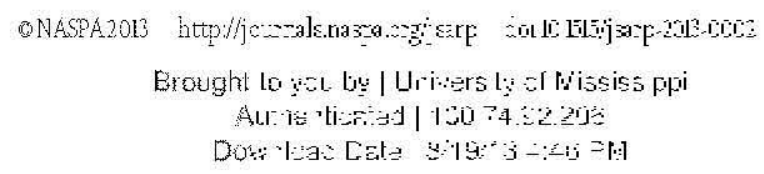


Table I

Participants' Demographic Information

\begin{tabular}{|c|c|c|c|c|}
\hline Pseudonym & Age & Year & Maijor & Race'Ethnicity \\
\hline Amber & 20 & Junior & =amily Commu niz $y$ Services & White \\
\hline Danielle & 20 & Senior & Agribu siness Managemen: & White \\
\hline Elizabeth & 21 & Senior & Agricul-ure Education & White \\
\hline John & 21 & Senior & Environmen:al Su dies & Sid not disclose \\
\hline Kevin & 23 & Senior & Agriculu ral Scienice & White \\
\hline Michael & 21 & Senior & Environmen:al Su dies & White \\
\hline Ruby & 20 & Senior & Human Rela-ions and ${ }^{3}$ sychology & Lebanese-American \\
\hline Sandra & 24 & Senior & Agribu sirıess Managemen: & White \\
\hline Tony & 21 & Senior & Jarks anid Recrea-ion & White \\
\hline
\end{tabular}

believe will impact your beliefs in the long term?" The follow up interwiew focked or participarts reflections and transition back to the United States Szecific cuestions included. "As you reflect back on your experiences, what stands out the mose to your?" "Have you come back from your experiences forever changed in any way?;" and "If a friend of yours was going to study abroad ir. Australia or New Zealand, what would you tell him or ker a hot.t your experier.ses?" To enstre trustworthiness (Creswell, 2007) in the data collected, the first author transcribed intervew data vertatim and sent synopses to participants after the second set of interviews.

Finally, upon return to the United States the first author sollectec anc copiec the reflection journals of interview participants, in which they wote thrnugkout the totr as a formal course requirement. Students were asked to writeabout specific topiss le. . "How haveyour new surrouncings affected your behavior and choices?", and "What iceas and lessons learnet on the trip will you take home with you?") in addition to sharing their nbervations. The jotrrals prowided additional context about the interactions among students while or the trip.

\section{Analysis}

Both authors analyzed the data, initially reading through onserration notes, ir terriew transcripts, and journal entries independently with an eye towand students' urderstanding of themselves, their role in the cohort, and in teractions in the host countries. Then, we met and focusst or understanding the interaction of each participant and the context. We first noted characteristics of students (e.g, that Michael was patriotic and Amber felt different than otters) anc discussec. tow these characteristics affected their interactions with zeers anc. navigation of the lost countries. 
In the process of discerning the students' characteristics, we roted that sereral participarts had essentially named themselves, using categories to descri fe themselves in relation to their irteractions with peers and study abroad experience (e.g.: lorer, modiator). Others used deseriptions to which we applied a name (e.g., messenger, learner)

One benefit of both authors not serving as zarticipant observers was that the second author asked numerous questions that helped the first author reflect on her osservations anc compare them with the data. Wewere careful not to assume that inconsistencies in nur aralyses restleed from our differing roles, rather we discussed them and referrec to the cata to clarify our interseretations.

\section{Limitations}

Despite our focus on students' peer relationships ard irceractinns with the kost countris, our interview questions did not explicitly ask studerts a joct their mes ard interastions with other students, enabling our themes to emerge organically without forcing disingenuous reflection. Had we focused more acutely on their roles and interactions in the interviews, we may have gained additional insights about the influence of the colort on students experiences. Second: although the entire group of students was observed and variation ir sampling ncctrred, rot all stcdents were interviewed, raising the potential that other findings may have emerged had we interviewed all students within the group. Furthermore our sample, while reflective of the entire grouz in terms of race and ethnicity, was relatively homngenots, makirg it impossi ble to draw irfererses about race or ethnicity.

\section{Findings}

In the context of their shared microsystems (Timrfen irerrer, 993 ), the study a road setting, we found that most students spent considerable time and energy sor.serred inot. the cohnor and their role in it, as revealed by observation notes, jourral er tries, and ir terriews. The design of the trip, with everyone traveling together, forced scudents wo malke desisinns several cimes a day about with who to sit on the bus, eat, and room as we switched hotels. These decisions recessitated that students attend to their role in the group, which revealed their cevelosmentally instigative characteristics, a key element of Bronfenbrenner's (1993) model. Some students welcomed the idea of changing seat mates or roommates whereas others pleaded with the trip Facilitators to keepererything the same. The data illustrate how students apsroached and exzerienced the trip cifferently:

Of the nine students who completed both irteriews, seren discussed their roles and irteractions in the group and with the host countries (e.g: interactiors with penple, fond, activities) ir detail. The description of their interactions revealed their selective resporsivity (Bor fentrenrer, 1993) to the environment and illustrated their personal stims:lus characteristics (Timr fenbrer rer, 1993) in relation to other students and the host colntries. Furrhermone, their dirsctive beliefs (Bronfenbrenner, 1993) were exposed by their response to their experience Two stederts dis-

JSARP 2013, 50(1)

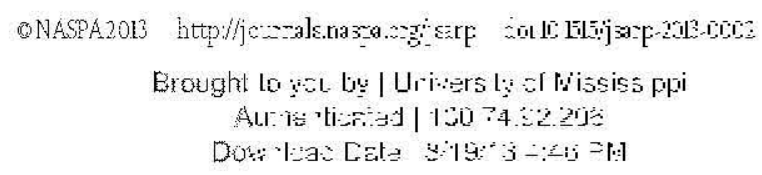


cussed feelings of loneliness and awkwardness in relation wo the group ard kost wotn tries, describing themselves as loners. Two others discussed their roles as medidtos descrioing themselves as at tending to group conflicts and working to make certain that everyone in the cohort felt welcome, sometimes even when interacting with people from the host cour tries. One more discrssed how: he felt compelled to make sure that others in the cohore saw their study abmad experierce and irteractions with the host countries from his perspective; we labeled him a mostger. The last two described themselves listening to and observing memters of the group anc bost countries to reflect on their perspectives and learn from them; we lialed them icariurs. These la jels were a product of students's self-identification or description counlec with our interyretation from the osservation notes, interview transcripts, and journal ercries. The labels are rot meart to imply that strdents were one dimensional, but rather reflect the dominantcharacteristics of their uncerstanding of their cohort and host country interactions. Tielow, we discuss the categnies of stzderts that emerged.

\section{Loners}

The two loners in the group, Amber and Darielle, described experiensing aw wwardness and isolation within the cohort. When asked to recot.r. her experier.es non the trip, Amber explaired that theaspect that stond out most to herwas how she struggled while shewas there. Ske explained, "I kind of felt like loner, I felt like I didn't fit in ... anc, I had a hard time" She revealed ker selective responsivity to the environment (Bronfenbrenner, 1993) when she attrisuted ker cifficulty fitting in to differences in values, sharing that she is the cype of zerson who lizes to stick with one person and no one on the trip held similar values. She explaired.

I definitely had a personality clash with a lot of the peogle. I mean. I could get along with them, and I came from the same background as them [her father was a farmer]. b.t. my ileas and values were much different than what theirs were. And. it wasn' just ajout the crinking; it was about the bigger issues.

Amber spent ample time reflecting on her role in the cohort, fretting about it daily witl peers, writing about it in her journal, and discussing it in decail ir both irterriews is alltded to above, she also was prenccupied by her peers drirkirg behavines, believing that her decision not to drink separated her from them. In her journal Amber wrote, "jim I ore of the very few penple who are going to be sober for the majority of the trip?" Durirgotr iritial in terwiew she expanded on her concern, "I have been uncomfortable with the fact nur gmop [kas] used [the trip] to get away from home and to party. ... That's really something that I ve strugglec with." Amiver felt lictle agency ia directive belief; Bronfenbrenner, 1993) in addressing the sictatior. she explained, "I cant expect everyone else to be like me, and I just have to accept that, and it's not recessarily worg. its just different."

Like Amber, Danielle experienced bouts of awkwandress ard isolatior withir the cohorc. Ir our initial interview, Danielle discussed her selsctive resporsivity (Tirnfer irerner, :993) wo the

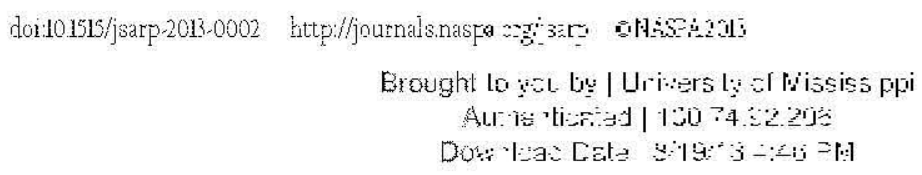


study abroad experience, explaining that she apsroachec the cohorr $v y$ "floar[ing] around to different people" and sometimes, around certain penple, got the feeling that they didnt really wart her there. Later in our follow-up interview, Danielle discussed kow her struggle with the group had been a catalyst for her to take charge of her experience, which ill-strated her directive beliefs (Bronfenbrenner, 1993). She explained, "I can't sit back and let somennedse ry to malestreI havea good time, I have to be in charge of it myself." As a result of her feelings of inssctrity or the trip, she became moreaware of the need for her to be moreassercive a bor. with whom and how ske sper. her time so that others' actions did not affect her as much.

Absent from Amber's and Danielle's obserratiors and trderstanding of their experienses were meaningful interactions with people in the hos countries, eltcidating their selestive responsivity (Bronfenbrenner, 1993) to the host countries Alttougt. both sommented on cifferences jetween the United States and Australia and New Zealard, they rarely ergaged with people from the host countries, gleaning the differences primarily throughosserwation. For examzle, when Amber discussed differences in lifestyle and relationshiz roles, she exylaino that she ziczed up on the differences by "observing people on the street, in restaurants, anc on the farm stay" but dic not mention talking to people from the host countries. Darielle also described her overeratiors of the culture from a distance, assuming they were similar to her experierses. Ske explained, "the penple in New Zealand are very laid back, and since they are all very rural, most of them are pretty 'small town', kind of like it is in my town."

\section{Mediators}

The two mediators in the group, Sandra and Ruxy: ayproacked their surrouncings ty attencing to group conflicts and working to make certain that everyone in the colort felt welcome Sancra described herself as a "mediator" and "leader" who snught. wo assist nother studer ts with navigating their cohort experience. In her journal entries and interviews, ske refererced her role as a modiator, discussing how she helped resolve conflicts that emergo in the cifferent cliques. She explained that she wanted to be "buddy-buddy" with everyone, and hearse she was the oldest on the trip, saw it as her responsibility to model tolerant beharior. Ferhaps jesaluse of these persoral stimelus characteristics (Bronfenbrenner, 1993), many peozle confided in ter about their disagreements with other students. Sandra listened to these students; affrming their persyectives anc offering advice about how to navigate differences and personality sonflizts Sancra crecitec the trio with bolstering her ability as a mediator, explaining her realization that servirg ir the role was "ir her nature" because so many students had confidec in her. Her insight revealed how ker interactions within the cohort strengthened her directive beliefs (Bronferbrenrer, 1993 ).

Ruby also took on the role of a mediator, secking to include everyore ir the cohort. Diring the first few days of the trip, Ruby's journal entries cetailet ker selective resconsivity Bronfenbrenner, 1993), spelling out her strategy for creatirg a welcoming cohort, ir cluding "talkirg to averyone and learning their names." One week in to the trip, Rc.by's observations nevelad her woroerr

JSARP 2013, 50(1)

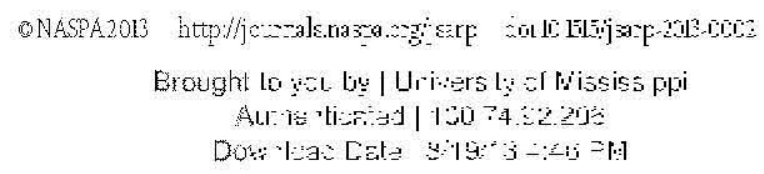


that some of her peers were not open to trying new thirgs ard her desire to "help them let go of whatever is holding them back." She described a sictatior in whick two of ker peers were disct saing vegetarianism. The issue was particularly cor tested healuse none of the strder.ts was a regetarian and the other student's family made their livelihond raisirg livestnck. Ruby said ore of the strdents made a comment that "vegetarians don't urdersard, ard they will rever understard, there's no way that you can reason with them — but they are wmorg" she disctissed her desire wo help both students see the issue from one another's perspective, and her direcive heliefs tTimofentrenrer, 1993) enabling her to do so.

Sandra and Ruby both discussed how their mediatior mles serred them in ir teractinns with people in the host countries, each drawing examples from interactiors with lncals at bars sandra recounted a story of being with friends and encotnterirg an intoxisated iustraliar whowas malking inappropriate comments to her friend. She explaired that since she was more sojer than the rest of her friends, she "felt like she had to protect her [friend]" ard so ske stepped ir and tried to mediate the situation. When it became clear to her that the man was rot gning to apolngi-e, Sardra "gathered up [her] friends" and left the bar.

Ruby also described attempting to mediace a situation setween ker, some friencs: and an Australian. She explained that while at a bar, the Australian cor fronted them a jout the LIS president. She responded by asking, "Well, weren't you going to ask me first if I wotec for him, or what my opinion was?" When he continued to badger ker, she cour. tered with, "I am really snrry, ju.t yot: offended me and my friends, and I would really aporeciate it if you woulc leave us alone:" Rusy explained that although ultimately the man apologiesd, whish made her feel like her mediatior strategy worked, she felt uncomfortable about the exchange It is clear from their descriptinns that both Sandra's and Ruby's directive beliefs (Bronfer orerner: 993) a hot.t their mediation abilities were not limited to their cohort interactions, bu rather, played a role in their inceractiors with the host countries as well.

\section{Messengers}

Michael was the sole messenger in the sample, fekaing as an envor to the gmotp and dictating to the cohort how to experience study abroad pmperly. He expected his peers to share a similar approach to the trip as his, revealing his belief that their selective responsivity (Bomrfenbrenrer, 1993) was wrong. Early in the trip, he commented ir his jot rral that ke wishad "more of the group? [was] socializing after the day's events are over." He ex-lainoc that going out to sars at night and interacting with locals was a gond way to get "a full experience of the cr:lttre", ard he was pronoc:pied that other students were missing out. On sereral nocasinns ke pestersd other studer ts to joirthe cohort at the bars at the end of the day despite their discomfort.

Michael also felt that other students were not as engaged ir. the trip as he was, revealing his selective responsivity (Bronfen brenner, 1993). When asked to prowide an example, he explaired that some people chose not to do certain activities (like bunge jumping or hang glidirgl because 
they cost too much money. He asserted that wher stederts are half way around the world, they should take advantage of every opportunity to "seize the day" no matter the cost. Wichael also discussed his dismay at others when they were not appopriately moved by their experiences. While in Australia, students visited the Australian War Yemorial. which commemorates the sacrifices of Australians who died in war, and includes a shrire dedicated to unknowr soldiers ard a miser.m. In his journal, Michael reflected on the disengaged setavior of several of his zeers during the visit, explaining "I was disappointed with how bored everyone semed [at the War Memorial]. I honestly don't think they understand what the term unkriomil soldor mears. . " Wich:ael discrssed his perspective regarding the War Memorial again durirg otr follow - t.p interview. He commerted that his classmates "just didn't get it" and were "spoiled" bscatse they did not appropriately respord to the memorial.

Michael's strong directive beliefs (Bronfentrenrer, 1993) and desire wo have others' skare his views and experiences pervaded his interactions with the host sot. r.tries Ir describing a corwersation with his host family during the farm stay in New Zsaland, Wishas explaired that they were "old-fashioned" and had strong opinions about "how nur automotive industry is going dowrhill and [our] president doesn't know what he's doing". "Wichalel felt like it was his role to "set the reoord straight," since "I would definitely know more a jout my own country than this guy would."

\section{Learners}

The two learners in the sample, John and Elizabech, disctised their selective resporsiwity (Bronfenbrenner, 1993) in relating to the cohort: and soecifically tow their interactions ausec them to reflect more deeply. John, a self-describe "environmentalist;" cescriba a ciscussion he had with some students in agriculture-based majors He expressed strprise at the fact that the agriculture students had similar views about the envimrmert and came away from the corversation with the understanding that "we all [are] necessary. Bnd that the best way to impmoe thirgs would be to combine ideas and work together." He explaired.

Were really not that different from each other. Wie tave a lot of the same ideas, it's just the sterentypes are there, it's hard to break them dowr ir a normal sicuation, bec when yot re thrown together for this amount of time-here togerher with everyore all the time-yot: learn to break those down a little bit, expanc on what you znow.

Elizabeth also shared several situations where ske learred from listerirg to ard ovserving other members of the cohort. She described how listenirg to and irteractirg with her diasmates compelled her to think more deeply about her experiences Ske explairsd,

Being around the group, the first couple of days, I idn't as $z$ that many cuestions, I just kinc. of observed the other kinds of questions that everybody else was askirg. I noted that they were deeper, meaning that they would sex something: jut then they would conrest it to something else. [Through their example,] I slowly hegan to pisce together some things.

JSARP 2013, 50(1)

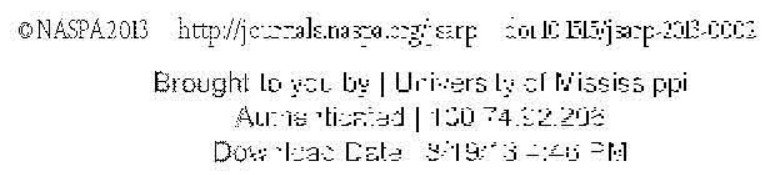


Eli-abeth observed others' selective responsiwity (Tirnnfer orerner. 1993) ard adopted their strategies to bolster her learning. She used that strategy to reflect on what she was learning and also to change her behavior upon return to the Urited states.

Elizabeth discussed her realization during a wholegrou reflection that peosle often talked about cultural differences in conservation but didnt learn from them orchange their tehavior. She shared an "aha moment" that ultimately changed ker diretive jeliefs (Bronferbrenner, 993) toward conservation, explaining that after observing others, she seame convincoc ste sossessoc the agency to make a difference. She observed how the cohort woulc.

Talk about "this and that" is wrong with Bmericars ard "this ard that" is rigkt with Australians, and how [Australians] do this better, sut [Americans] co that better. .. It mace me realize that's what everybody does, we sit arnurd ard talls abot.t thirgs [and] . . that I need to take the next step and try to change it - to be part of the charge I want to see. Tiesaluse I was in a different country... I was able to see a jetter way of doing something, taz [e] it, and apply it to what I do already.

The dynamic interaction of others' lack of commitmert to conservatior cotpled with examples of sustainability from the host countries inspired Elizabeth to reflect on and ulcimately transform her behavior. For example, in our follow up interview, she described encouraging her family to take a smaller car on trips and to start compostirg their waste.

John's and Elizabeth's approach to people ir the host sotntry were also learrirgorier.ted. illustrating their selective responsivity and directive yeliefs (Bronferbrenrer, :993). Sore than any other student in the sample, Elizabeth discussed ir sigh ts she gaired fom sorrersations she had with the content experts. She recounted a discr ssimn ske kad with a sustairable farmer that inspired her to act more responsibly. She explained,

[The farmer] was so dedicated to hercause-ske saw that the area nesded to remair a marshlike atmosphere-and that was what she wanted to do, she wanted to preserve it. so she took it on herself. She saw a cause and went after it... I have awavs wanto to live lize that, really self-sustained.

Elizabeth reflected on the differences she perseived tewween the conservation walues teld wy the Australian farmer and the farmers she knew in the United States, sommerting that lorg-term land sustainability was not as explicit a goal in the Urited States.

John also described many interactions with people ir the host cultries, explairing that through the formal portion of the trip he met "ervimormertalists, agrizulttralists, ard sncial systems people, like either politicians or school teackers", 'xt y goirgour at righ he was ajle to meet "normal people, .. the garden variety of all different grous:" He ex-lainec that each time he went out he talked to at least one or two people and got to krow them, ill.strating his selective resporsivicy (Bronfenbrenner, 1993) to his surroundings. These interactions sals sed him to be moreoper minded because he heard different perspectives on everything from agriculture to international issues 


\section{Discussion}

Students' differing developmentally instigative characteristics, more than their demograshic characteristics, shaped their approach to peers ard experierces ir the host cotntries, extending Bronfenbrenner's (1993) ecological systems thenry to the context of strdy a imad ard illistrating the importance of considering the person and cortext tngether. The mix of these characteristics caused anxiety for some students (like the loners) ard deepered learrirg for other students (like the learners). For example, both Amber (a nondrirker and passive onserver) and Darielle Isomenne who floated from group to group) had personal stimulus characteristics (Bronfentrenner: 1993) that inhibited their connections with others in the group ard penple ir the host ontr.rries Ir cortrast, by virtue of John's and Elizabeth's curiosity about the erwirnmert ard willirgress to listen, which demonstrated their selective responsivity (Bronferbrenrer, 1993) they ergaged sor tent experts more often than other students did. As might ke expected, the content experts respondec positively, which led these students into deeper learnirg-orier ted discr. ssinns.

Students' developmentally instigative characteristics (Bmofentrenrer, -993) also explair why they took on certain roles within the cohort or chose w ir teract in certain wys with mem iers of the host countries. For example, from the begirning of the trip? Ruby socght to know everyone and help them get along, and Sandra felt obligated to act responsibly and me model tolerart hehavior. Because of their behavior, these women were seer as trustwortly sot res for nthers wo share their frustrations. Ruby's and Sandrảs personal stimelus charateristics (Timrfen irerrer, 993 ) shaped how they interacted with their peers (selsctive respor-sivity. Bronferbremer. 1993) ard directive beliefs (Bronfenbrenner, 1993) in serving as mediators-rltimately empowering them to serve as in termediaries with people in the host cort r.tries.

Michaels role as an envoy can also be explaired ir part by his developmertally irstigative characteristics. Among his strongest characteristiss were his dinetive jeliefs (Bnorfenbrenrer, 1993), as he portrayed a clear sense of conviction in his viewpoints ard spert ample time corveying them to others. This conviction, coupled with his "sei-e the momert" mentality, meart that he regularly sought out new experiences and insisted others try new thirgs tno Furthermore, he often discussed his viewpoints with other members of the cohort and hos countries Although he invited others to share their differing perspectives a personal stimulus characteristic: Bronfenbrenner, 1993), Michael did not consider their views, preferrirg that they adope his points of rewe

The findings also underscore the importance of helping sudents to foster meaningful interactions in the host countries to deepen cross culttral ergagement. Urless students were irclired to explore host country interactions by virtue of their develomentally instigative characteristics (like the Messenger or Learners), they reported very few, illts strating the need for facilicators to $x$ mindful about ensuring all students have meaningftrl npporttrities to ir teract with posple in the host countries. Facilitators play a vital role in secting expectations for interactions anc helping students interact with and reflect on their experiences with the host comntries. Lize the students

JSARP 2013, 50(1)

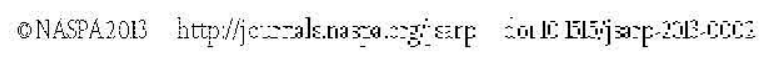

Brought to yo be | Uriters l: or hississ ppi

Aur is ti:

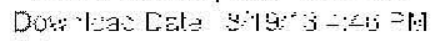


in Ransbury and Harris's (1994) study, our students keneficted from reflection time because they were encouraged to direct their gaze at the host cor r rries. The fact that stc-derts described learring more from peer in teractions (like Mediator Sandra disonerirg that helpirg others to regotiate conflict was in her nature and Learner Elizabeth adosting others' learning strategies to jolster her learning) than from interactions with the host conntries illsstrates that more mist be dore to help students meet the potential of study abroad as a rick sdration:al cortext.

\section{Implications for Practice}

The findings of the study illustrate the importance of attencing to students' varying developmentally instigative characteristics and peer relatiorskips wher plarning and leading stcdy abroad programs. For the Loners, one of the enduring memories of their entire experiense was their struggle to be part of the group. To reduce the amotint and degree of arxiecy Loners forl, study abroad facilitators should vary activities so that studerts have the opportcnicy to interast with all other students (using some meal times for small-group reflectionsor assigning a topic anc. students to small groups so they can discuss their experiences) so that students develop dexper connections to each other. Facilitators should also pay attention to the socess of grou formation: setting ground rules for cohort interaction (such as tratirg each orher with respeat) ard encouraging them to get to know one another.

The group's Messenger would have benefittec from active learning activities that encouraged him to listen to peers perspectives in additior wo sharirg his perspective These activities may include writing journal entries where he was asked to compare anc contrast ć.fferent zersyectives. Engaging with and reflecting on his and others zerspectives invites the rlessenger to ex zand his viewpoint and add complexity to his thinkirg, which may adwance his congritive developmert (Baxter Magolda, 1999). The Facilitators should erstre that there are ample opportunities for stsdents to engage their varying viewpoints, adding reflection sessions and rowicing structured dis cussion during travel days.

The Learners clearly benefitted from engaging with others, both zeers anc peole in the tost countries. In addition to the large group reflection sessions, learners might Jenefit from otter opportunities to in teract with members of the cohort throught small gmop dissussior. Also, becat:se Learners and Mediators seemed to rise above the group conflict, they might be helpful resources in making the Loners feel more welcome.

In addition to being more attentive to intragrou cynamiss, study a roac facilitators should also provide ample opportunities for formal and informal irceractions with the host countries. These opportunities should extend beyond time at a sar after the cays formal activities are over and should include more than a single content expere (e.g., park rarger. Farmerl whose time will likely be dominated by Learners or Messengers ( $b$ wircue of their dewelopmertally irstigatirecharacteristics). Faculty might consider connecting with a local universicy to nrganize meals or other 
interactions with local students who share similar irterests or majors. In additinn, facilitators should investigate whether there are community service npporttrities that would put students in close contact with local communities. These ir-teractions will help to facilitate connrections with the host countries for all students, regardless of their derelopmer tally ir stigative characteristics because they will be forced to engage with the host colr.rries.

As the demand for short-term, cohort-base programs continues to rise, student affairs ex. cators and faculty must grapple with study abroad as a grocpexperience. The zcrrent scudy illustrates how students' varying developmentally instigative characteristics affect their experiences within their cohort and interactions with the tos countries The fincings call for study atroad facilitators to understand study abroad as a group experience in onder to foster group ard cultral interactions that promote growth in students' understanding of themselves, others, ard the host countries. Additional research is needed to determine podagogy that enajles Facilitators to t.tili-e a cohort effectively to promote cross cultural learning.

\section{References}

Baxter Magolda, M B. (1999). Engaging students in active learning. In G. S. Blimling \& E. J. Whitt

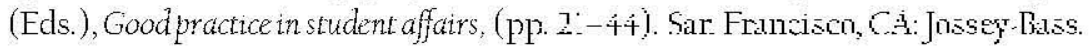

Broido, E. M., \& Manning, K. (2002). Philosophical fourdations and surrert theorecical perspec-

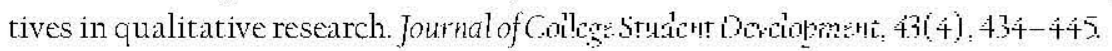

Bronfenbrenner, U. (1993). The ecology of cognitive development: Resench models ard fugitive

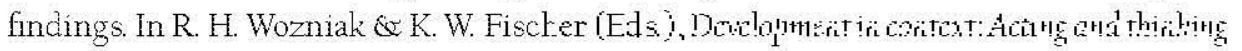
in specificenvironments (pp. 3-44). Hillsdale, NT: Erlbaum.

Brubaker, C. (2007). Six weeks in the Eifel: A case for cr.ltire learnirg during skort-term study abroad. Die Unterrichtspraxis/7eaching Germeri, 40(2), :2-:23.

Chieffo, L., \& Griffiths, L. (2004). Large-scale assessment of student attitudes after a stort-term

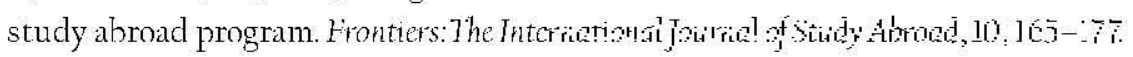

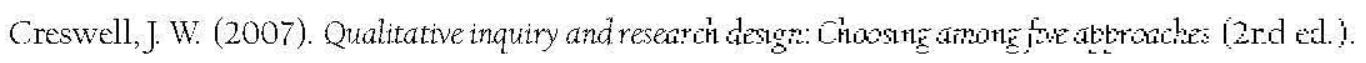
Thousand Oaks, CA: SAGE.

Dwyer, M M (2004). More is better: The impact of stucy asroac program curation Frotiturs: The Interdisciplinary Journal of Study Abroad, 10, 15:-164.

Engle, L., \& Engle, J. (1999). Study abroad levels: Toward a classification of zrogram ty zes. Firmtitr: The Interdisciplinary Journal of Study Abroa $1,5,1-19$

Ingraham, E. C., \& Peterson, D. L. (2004). Assessirg theimpact of stc.dy abroad nu stc.dent learring

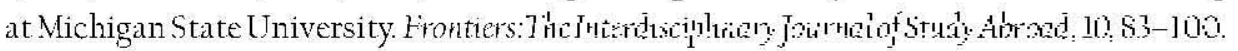

JSARP 2013, 50(1)

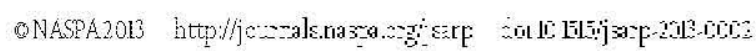

$$
\begin{aligned}
& \text { Brought to yo be | Uriters l: or hississ ppi }
\end{aligned}
$$

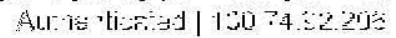

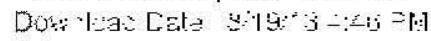




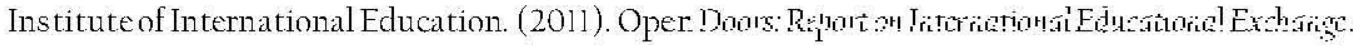
New York, NY: Author.

Jessup-Anger, J. E. (2008). Gender observations and study a imoad: How students reconcile consz-

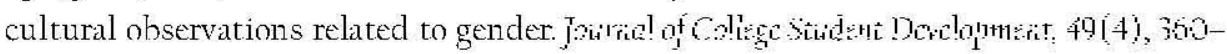
373.

Lawrence, R. L. (2002). A small circle of friends: Cokort groups as learring commr.rities. In D S

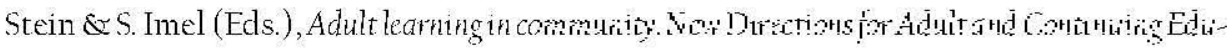
cation, no. 95 (pp. 83-92). San Francisco, CA: Jossey-Bass.

Lenz, W. E, \& Wister, J. A. (2008). Short-term abroac with long-term senefics Iritcrietiona! Edicitor, $17(3), 84-87$.

Paige, R. M., Fry, G. W., Stallman, E. M. Josic,J., \& Jor. J. (2009) Scudy abrod for glo al ergagemert:

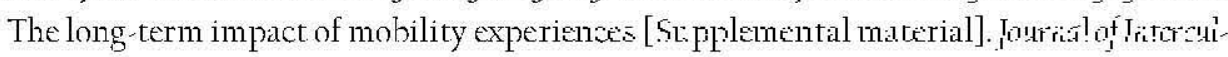
tural Education, 20, 29-44. doi:10.1080/146 599000330947

Patton, M Q. (1990). Qualitative evaluation and reserch mathd (2rded. I. New

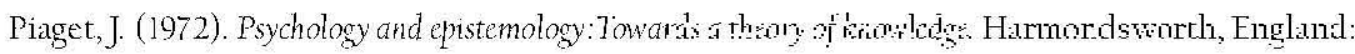
Penguin.

Ransbury, M. K., \& Harris, S. A. (1994). Study abrnad: The realicy of juilding dyramic gmep learning. Journal on Excellence in College Teaching, $5(2), 9 \bar{i}-10 \bar{i}$.

Renn, K. A., \& Arnold, K. D. (2003). Reconcepttaali=ing research nn college studert per cultt.re. Journal of Higher Education, 74(3), 261-29].

Rowan-Kenyon, H. T., \& Niehaus, E. K. (2011). One year later: The influence of stort-term study abroad experiences on students. Journal of Shident Ajar Resarch and Fractice, 48(2), 2:3228.

Twombly, S. B. (1995). Piropos and friendships: Gender and culture clisk ir scudy abroad. Frotturs: The Interdisciplinary Journal of Study Abroa $1,1,1-2 \bar{i}$.

Yin, R. (1984). Casestudy research: Design and methads. Tiewerly Hills, CA: SAGE. 